\title{
SUNDAY CLOSING LAWS: \\ Protection For Small Retailers?
}

\author{
Douglas W. McNiel \\ McNeese State University \\ Lake Charles, Louisiana \\ Shirley S. Yu \\ Denison University \\ Granville, Ohio
}

\begin{abstract}
"Blue laws" which prohibit the Sunday sale of certain merchandise are an example of public policy regulations affecting small businesses that have been the subject of much controversy and heated debate but little research. Opponents argue that Sunday closing laws are an unnecessary impediment to retail trade and that their elimination would lead to increased retail activity. On the other hand, proponents of blue laws contend that allowing Sunday sales simply redistributes the same level of retail activity over seven days rather than six, and that the increased costs of doing business leaves both consumers and retailers (especially small retailers) worse off.
\end{abstract}

\section{Background}

Sunday closing legislation in the United States is most prevalent in the East and South, whereas states with no restrictions or limited restrictions tend to be concentrated in the Midwest and West [1]. The trend in recent years has been toward liberalization or repeal of Sunday closing laws. Since 1961, general restrictions on Sunday sales have been repealed in twelve states [6].

In the public policy debate over Sunday closing legislation, small businesses tend to support blue laws and large chain stores tend to lobby for repeal. In states with Sunday closing laws there are numerous examples where owners of small shops turn in larger competing establishments that violate the blue laws [6]. If Sunday closing laws protect small retailers from the competition of larger, more efficient firms on a day of the week with the potential to result in the largest dollar-volume-per-hour for shopping center operations [4], then Sunday closing legislation may be crucial to the survival of many small retailers.

Despite the controversy and debate over public policy toward Sunday sales, there has been relatively little broad-based empirical research regarding the impact of Sunday closing laws on small retailers versus large retailers. This study examines the effect of blue laws on (1) the total level of retail activity, (2) the number of retail establishments, and (3) the size of retail establishments.

Journal of Business Strategies, Volume 6, Number 2 (Fall 1989) 


\section{Literature Review}

Most published empirical research on the impact of Sunday closing laws has been limited in scope to a particular retail subsector, such as grocery stores ([10], [7]); to particular types of stores, such as shopping center chain stores [5] or small retailers in a limited geographical area [3]; to the profiles of Sunday shoppers [2]; or to the reasons blue laws are enacted and repealed [8]. It is difficult to draw conclusions about the issues listed above from these studies since none utilize a very broad data base.

In the most comprehensive study to data, Laband and Heinbuch [6] compare a nonrandom sample of ten states which enforced blue laws throughout the 1970 s and ten randomly selected states without blue laws. They conclude that Sunday closing laws lead to an overall reduction in the level of commercial activity, as well as fewer and smaller retail establishments. In their view, "opening Sundays to commercial activity has the net effect of (1) increasing the total amount economic activity, not simply redistributing six days worth of sales across seven" ... and (2) benefiting large stores without hurting small stores (defined alternatively as establishments employing less than 100 and 500 workers) [6, pp. 191, 193]. However, when small firms are defined less aggregately (as firms with 1-4, 5-9, 10-19, 20-49, 50-99, 100-499 workers), Laband and Heinbuch conclude that "Sunday-closing laws constitute a political weapon with which small businesses circumvent the competitive pressures that might otherwise reduce their numbers" [6, p. 198].

While Laband and Heinbuch present one of the most ambitious empirical studies of blue laws to date, it must be taken as more illustrative than conclusive because of (1) the small, nonrandom nature of the sample, (2) the lack of statistical tests to evaluate the significance of apparent differences between blue law and non-blue law states, and (3) the failure to adjust for other things that may not be equal between blue law and non-blue law states. Do these same conclusions apply when the retail sectors of all blue law and non-blue law states are compared, taking into account other factors that may be responsible for differences between states with and without Sunday closing laws?

The objective of this research is to fill in the gaps and alleviate the deficiencies associated with previous empirical work by (1) comparing data from a representative sample of all retail firms operating in all jurisdictions with and without Sunday closing laws in the United States, (2) testing for the statistical significance of apparent differences between blue law and non-blue law jurisdictions, and (3) adjusting for other factors (such as income) that may account for differences between blue law and non-blue law jurisdictions.

\section{Data and Methodology}

Cross section data on the retail sectors in the 50 states and the District of Columbia were obtained from the Census of Retail Trade [11]. ${ }^{1}$ These data contain information

\footnotetext{
${ }^{1}$ A complete Census of Retail Trade with the broad regional data base necessary for this type of study is conducted only at five year intervals.
} 
on the level of retail activity, the number, and size of retail firms for a representative sample of all retail establishments operating in each of the 51 jurisdictions. Data on the presence or absence of Sunday closing laws were obtained from a survey by the Association of General Merchandise Chains [1].

In view of the argument that blue laws may have a differential impact on small firms versus large firms, two subsamples of retail establishments also are examined for each jurisdiction. One subsample represents only the very small "mom and pop" retail operations without a payroll. The other subsample represents only larger retail establishments with a payroll and excludes "mom and pop" operations. The effect of Sunday closing laws on each group is examined. Since there is a possibility that blue laws may not affect the retail sector as a whole in each jurisdiction, but may affect the distribution of retail trade among various types of retail establishments, differences among the ten major two digit subsectors of retailing (listed by SIC code in Table 1) are also examined for each jurisdiction.

Table 1

Description of Major Subsectors of Retail Trade

\begin{tabular}{ll}
\hline SIC 52 & $\begin{array}{l}\text { Building Materials, Hardware, Garden Supply, and } \\
\text { Mobile Home Dealers } \\
\end{array}$ \\
SIC 53 & Foneral Merchandise Group Stores \\
SIC 54 & Automotive Dealers \\
SIC 55 (Except 554) & Gasoline Service Stations \\
SIC 554 & Apparel and Accessory Stores \\
SIC 56 & Furniture, Home Furnishings, and Equipment Stores \\
SIC 57 & Eating and Drinking Establishments \\
SIC 58 & Drug and Proprietary Stores \\
SIC 591 & Miscellaneous Retail Stores \\
SIC 59 (Except 591)
\end{tabular}

The methodology initially assumes (as in the Laband and Heinbuch study) that all other factors except population are equal between the jurisdictions with blue laws and the jurisdictions without blue laws. The effect of blue laws on the level of retail activity, the number, and size of retail establishments is measured by examining differences in the means between blue law and non-blue law jurisdictions of the (1) retail sales per capita, (2) number of retail establishments per 100,000 population and (3) retail sales per establishment. Next, to correct for a deficiency in previous work, the effects of differences in both population and per capita income are taken into account by comparing (4) retail sales per hundred dollars of effective buying income in each jurisdiction. ${ }^{2}$

\footnotetext{
${ }^{2}$ For the definition of a jurisdiction's effective buying income see Sales Marketing \& Management, "Survey of Buying Power," annual issues. Retail sales per hundred dollars effective buying income $=($ Retail sales per capita $) /($ Per capita effective buying income $/ \$ 100)=$ Share of each $\$ 100$ income spent on retail goods and services.
} 
To test for the significance of apparent differences between blue law and non-blue law states, the null hypotheses in each case are that the variances in the two groups are equal and the means in the two groups are equal. Slightly different $t$-tests are used for evaluating differences in means of the two groups depending upon whether the variances are found to be significantly different [9].

\section{Empirical Results}

An examination of the representative sample of all retail establishments operating in the 50 states and the District of Columbia suggests that Sunday closing laws have little impact on the overall level of retail activity or the average number or size of all retail establishments. However, when this sample is separated into two parts-very small retail establishments without a payroll and larger retail establishments with a payroll-the effects of blue laws become more apparent.

\section{Retail Sector as a Whole}

Analysis of data from the sample of all retail establishments (Table 2) suggests that the aggregate impact of Sunday closing laws is relatively minor for the retail sector as a whole. A comparison of the data for blue law and non-blue law jurisdictions indicates that the volume of retail sales per capita is slightly lower on average in states covered by blue laws, $\$ 4,547$ vs. $\$ 4,890$. But this measure of retail activity adjusts only for differences in population among the two groups of states. The concentration of blue law states in the South where per capita income, and therefore retail sales per capita, are traditionally lower may be partially responsible for this result. Comparing a measure of retail activity that adjusts for differences in both population and income yields the opposite result. Retail sales per $\$ 100$ of effective buying income are slightly higher in states with blue laws, $\$ 52.18$ vs. $\$ 51.24$. Both the number and the average size of all retail establishments are slightly smaller in blue law states. However, none of the differences reported in Table 2 are found to be statistically significant.

\section{Small Retail Firms}

Data from the sample of very small retail establishments (Table 3) suggest that Sunday closing laws do provide some protection for small retailers. Adjusting for differences in both population and income, a significantly larger share of effective buying income is spent in very small retail establishments in states with Sunday closing laws, $\$ 1.56$ vs. $\$ 1.29$ per $\$ 100$ effective buying income. These figures imply that if the small retailers in the 18 states with Sunday closing laws at the time of the sample were no longer afforded the protection provided by blue laws, these small retailers would loose annually almost $\$ 2$ billion in sales or slightly over $17 \%$ of their business. While Table 3 shows no significant difference in the number of small retail establishments, sales per establishment for very small retailers are significantly increased when blue laws are present, $\$ 49,176$ vs. $\$ 42,895$ per establishment. 
Table 2

All Retail Establishments: $t$-tests for Differences in Means Between Blue Law and Non-Blue Law Jurisdictions.

\begin{tabular}{|c|c|c|c|c|}
\hline & \multicolumn{2}{|c|}{ Means for States } & \multirow{2}{*}{\multicolumn{2}{|c|}{$\begin{array}{c}\text { Test of Differences } \\
\text { Between Means }\end{array}$}} \\
\hline & \multirow{2}{*}{$\begin{array}{r}\text { With } \\
\text { Blue Laws } \\
(N=18)\end{array}$} & \multirow{2}{*}{$\begin{array}{r}\text { Without } \\
\text { Blue Laws } \\
\left(N^{\prime}=33\right)\end{array}$} & & \\
\hline & & & $t$-value & $\begin{array}{l}\text { Signifi- } \\
\text { cance }\end{array}$ \\
\hline $\begin{array}{l}\text { Level of Retail Activity Measured by: } \\
\text { (1) Retail Sales per Capita }\end{array}$ & $\$ 4,547$ & $\$ 4,890$ & 1.59 & \\
\hline Buying Income in the Jurisdiction & $\$ 52.18$ & $\$ 51.24$ & -0.59 & \\
\hline $\begin{array}{l}\text { Number of Retail Establishments } \\
\text { Per } 100,000 \text { Population in the } \\
\text { Jurisdiction }\end{array}$ & 867.89 & 883.80 & 0.44 & \\
\hline Firm Size & & & & \\
\hline Retail Sales Per Establishment & $\$ 520,342$ & $\$ 543,998$ & 1.07 & \\
\hline
\end{tabular}

\section{Larger Retail Firms}

Consumers spend about $\$ 50$ out of every $\$ 100$ of effective buying income in the larger retail establishments (Table 4 ) and only $\$ 1.56$ or less of every $\$ 100$ effective buying income in the very small retail establishments (Table 3). For larger retail establishments as a group, the impact of Sunday closing laws appears to be less important (although redistributions within this group may be significant-see next section). For the sample of larger retail establishments, there are no significant differences between blue law states and non-blue law states in the level of retail trade (after adjusting for differences in both population and income), the number, or the average size of these retail establishments (Table 4).

\section{Redistributions Among Larger Retail Firms}

While the impact on larger retailers as a group appears to be relatively minor, certain types of businesses in the sample of larger retail firms may be significantly affected by Sunday closing laws (Table 5). When Sunday sales are restricted, a significantly smaller share of effective buying income is spent in larger eating and drinking establishments (SIC 58) and fewer of these enterprises remain in business. The number of general merchandise (SIC 53) and drug (SIC 591) stores is increased when blue laws are present, but the average size of these establishments is reduced. The average size of food stores (SIC 57) is also reduced when Sunday sales are restricted. 
Table 3

Very Small Retail Establishments Without a Payroll: $t$-tests for Differences in Means Between Blue Law and Non-Blue Law Jurisdictions

\begin{tabular}{|c|c|c|c|c|}
\hline & \multicolumn{2}{|c|}{ Means for States } & \multirow{2}{*}{\multicolumn{2}{|c|}{$\begin{array}{l}\text { Test of Differences } \\
\text { Between Means }\end{array}$}} \\
\hline & \multirow{2}{*}{$\begin{array}{r}\text { With } \\
\text { Blue Laws } \\
(N=18)\end{array}$} & \multirow{2}{*}{$\begin{array}{r}\text { Without } \\
\text { Blue Laws } \\
\left(N^{\prime}=33\right)\end{array}$} & & \\
\hline & & & $t$-value & $\begin{array}{l}\text { Signifi- } \\
\text { cance }\end{array}$ \\
\hline $\begin{array}{l}\text { Level of Retail Activity Measured by: } \\
\text { (1) Retail Sales Per Capita } \\
\text { (2) Retail Sales Per } \$ 100 \text { Effective }\end{array}$ & $\$ 129$ & $\$ 118$ & -1.35 & \\
\hline Buying Income in the Jurisdiction & $\$ 1.56$ & $\$ 1.29$ & -2.11 & ** \\
\hline $\begin{array}{l}\text { Number of Retail Establishments } \\
\text { Per } 100,000 \text { Population in the } \\
\text { Jurisdiction }\end{array}$ & 264.60 & 277.86 & 0.78 & \\
\hline $\begin{array}{l}\text { Firm Size } \\
\quad \text { Retail Sales Per Establishment }\end{array}$ & $\$ 49,176$ & $\$ 42,895$ & -2.97 & $* * *$ \\
\hline
\end{tabular}

Note: Difference of means significantly different from zero at the $1 \%\left({ }^{* * *}\right)$, $5 \%\left({ }^{* *}\right)$, and $10 \%(*)$ level.

Table 4

Larger Retail Establishments With a Payroll: $t$-tests for Differences in Means Between Blue Law and Non-Blue Law Jurisdictions

\begin{tabular}{|c|c|c|c|c|}
\hline & \multicolumn{2}{|c|}{ Means for States } & \multirow{2}{*}{\multicolumn{2}{|c|}{$\begin{array}{c}\text { Test of Differences } \\
\text { Between Means }\end{array}$}} \\
\hline & \multirow{2}{*}{$\begin{array}{r}\text { With } \\
\text { Blue Laws } \\
(N=18)\end{array}$} & \multirow{2}{*}{$\begin{array}{r}\text { Without } \\
\text { Blue Laws } \\
\left(N^{\prime}=33\right) \\
\end{array}$} & & \\
\hline & & & $t$-value & $\begin{array}{l}\text { Signifi- } \\
\text { cance }\end{array}$ \\
\hline $\begin{array}{l}\text { Level of Retail Activity Measured by: } \\
\text { (1) Retail Sales Per Capita } \\
\text { (2) Retail Sales Per } \$ 100 \text { Effective }\end{array}$ & $\$ 4,319$ & $\$ 4,652$ & 1.79 & * \\
\hline Buying Income in the Jurisdiction & $\$ 50.62$ & $\$ 49.95$ & -0.44 & \\
\hline $\begin{array}{l}\text { Number of Retail Establishments } \\
\text { Per } 100,000 \text { Population in the } \\
\text { Jurisdiction }\end{array}$ & 603.29 & 605.94 & 0.12 & \\
\hline $\begin{array}{l}\text { Firm Size } \\
\quad \text { Retail Sales Per Establishment }\end{array}$ & $\$ 724,798$ & $\$ 772,714$ & 1.48 & \\
\hline
\end{tabular}

Note: Difference of means significantly different from zero at the $1 \%\left({ }^{* * *}\right)$, $5 \%\left({ }^{* *}\right)$, and $10 \%(*)$ level. 
Table 5

Larger Retail Establishments With a Payroll: $t$-tests for Differences in Means Between Blue Law and Non-Blue Law Jurisdictions

\begin{tabular}{|c|c|c|c|c|}
\hline & \multicolumn{2}{|c|}{ Means for States } & \multirow{2}{*}{\multicolumn{2}{|c|}{$\begin{array}{l}\text { Test of Differences } \\
\text { Between Means }\end{array}$}} \\
\hline & \multirow{2}{*}{$\begin{array}{r}\text { With } \\
\text { Blue Laws } \\
(N=18)\end{array}$} & \multirow{2}{*}{$\begin{array}{r}\text { Without } \\
\text { Blue Laws } \\
\left(N^{\prime}=33\right)\end{array}$} & & \\
\hline & & & $t$-value & $\begin{array}{l}\text { Signifi- } \\
\text { cance }\end{array}$ \\
\hline $\begin{array}{l}\text { Level of Retail Activity Measured by } \\
\text { Retail Sales Per } \$ 100 \text { Effective } \\
\text { Buying Income in the Jurisdiction: }\end{array}$ & & & & \\
\hline (a) in SIC 52 & 2.76 & 2.71 & -0.20 & \\
\hline (b) in SIC $53\left(N^{\prime}=30\right)$ & 5.64 & 5.64 & 0.00 & \\
\hline (c) in SIC 54 & 11.59 & 11.27 & -0.55 & \\
\hline (d) in SIC 55 & 9.77 & 8.90 & -1.56 & \\
\hline (e) in SIC 554 & 4.54 & 4.83 & 1.10 & \\
\hline (f) in SIC 56 & 2.72 & 2.58 & -1.31 & \\
\hline (g) in SIC 57 & 2.00 & 2.09 & 1.08 & \\
\hline (h) in SIC 58 & 4.43 & 5.13 & 2.97 & *** \\
\hline (i) in SIC 591 & 1.67 & 1.75 & 0.92 & \\
\hline (j) in SIC 59 & 5.23 & 4.99 & -0.42 & \\
\hline $\begin{array}{l}\text { Number of Retail Establishments } \\
\text { Per } 100,000 \text { Population in the } \\
\text { Jurisdiction: }\end{array}$ & & & & \\
\hline (a) in SIC 52 & 34.15 & 32.55 & -0.45 & \\
\hline (b) in SIC 53 & 19.53 & 15.82 & -2.47 & ** \\
\hline (c) in SIC 54 & 82.29 & 72.24 & -1.71 & \\
\hline (d) in SIC 55 & 44.76 & 42.14 & -0.88 & \\
\hline (e) in SIC 554 & 53.48 & 53.41 & -0.02 & \\
\hline (f) in SIC 56 & 58.85 & 58.90 & 0.02 & \\
\hline (g) in SIC 57 & 40.68 & 41.60 & 0.59 & \\
\hline (h) in SIC 58 & 132.34 & 150.37 & 2.06 & ** \\
\hline (i) in SIC 591 & 24.01 & 20.70 & -3.14 & *** \\
\hline (j) in SIC 59 & 109.99 & 117.39 & 1.21 & \\
\hline $\begin{array}{l}\text { Firm Size Measured By } \\
\text { Retail sales per Establishment (\$) }\end{array}$ & & & & \\
\hline (a) in SIC 52 & 719,468 & 816,277 & 1.38 & \\
\hline (b) in SIC $53\left(N^{\prime}=30\right)$ & $2,769,628$ & $3,744,985$ & 2.80 & $* * *$ \\
\hline (c) in SIC 54 & $1,198,461$ & $1,459,611$ & 3.53 & *** \\
\hline (d) in SIC 55 & $1,930,312$ & $2,033,140$ & 0.85 & \\
\hline (e) in SIC 554 & 727,926 & 853,039 & 3.00 & *** \\
\hline (f) in SIC 56 & 399,818 & 424,527 & 1.01 & \\
\hline (g) in SIC 57 & 425,439 & 475,140 & 1.79 & * \\
\hline (h) in SIC 58 & 294,811 & 324,085 & 1.40 & \\
\hline (i) in SIC 591 & 605,016 & 852,426 & 2.79 & $* * *$ \\
\hline (j) in SIC 59 & 399,933 & 407,090 & 0.23 & \\
\hline
\end{tabular}

Note: Difference of means significantly different from zero at the $1 \%\left({ }^{* *}\right)$, $5 \%\left({ }^{* *}\right)$, and $10 \%\left(^{*}\right)$ level. 
The results for eating and drinking establishments are somewhat unexpected since these types of establishments are often exempted from Sunday closing laws. Apparently restrictions on Sunday sales induce potential shoppers to spend less on food and drink away from home- $\$ 4.43$ per $\$ 100$ effective buying income in states with blue laws vs. $\$ 5.13$ in states without blue laws (Table 4). In this instance one might conclude that blue laws penalize a subsector of retailing that is generally characterized by relatively small businesses.

In the other subsectors of retail trade where blue laws were found to have a statistically significant impact, the results lend additional credence to the argument that Sunday closing laws create an environment more favorable for smaller retail establishments. Blue laws tend to reduce the average size of general merchandise stores, drug stores, food stores, gasoline stations, and furniture stores.

\section{Implications}

While the aggregate impact of Sunday closing laws may be relatively minor, the impact on very small retailers does appear to be significant. The evidence suggests that blue laws provide a more protective regulatory environment that allows small retailers to capture a larger share of consumer spending.

Of course the success of small retail firms depends not only upon the regulatory environment in which they operate, but also upon the way they are managed. This study suggests that small retailers may have to manage their operations and market their services more aggressively if they are to survive without the protections afforded by Sunday closing laws.

Finally, there is evidence to suggest that blue laws may affect the distribution of business among the various retail subsectors. The results indicate that certain types of larger retailers may also do well to heed the advice of Barnes and Chopoorian [3] about developing marketing plans to target potential Sunday shoppers in order to avoid adverse redistributions when faced with a change in public policy toward Sunday sales.

\section{References}

1. Association of General Merchandise Chains. Summary of State Laws Which Restrict Retail Business on Sunday. (December, 1984) Washington, DC.

2. Barnes, N. G. "New Shopper Profiles: Implications of Sunday Sales." Journal of Small Business Management (July, 1984), pp. 32-39.

3. Barnes, N. G. and J. Chopoorian. "Small Retailers and Sunday Sales." Journal of Small Business Management (April, 1987), pp. 40-46.

4. Chain Store Age Executive. "Are Sunday Hours Really Profitable?" (April, 1970), pp. E19-21. 
5. Chain Store Age Executive. "Survey Shows Center Stores Should Open Sunday: Profitability Cited" (December, 1979), p. 10.

6. Laband, D. N. and D. H. Heinbuch. Blue Laws: The History, Economics, and Politics of Sunday-Closing Laws. Lexington, MA: D. C. Heath and Co. (1987).

7. Moorehouse, J. C. "Is Tullock Correct About Sunday Closing Laws?" Public Choice, Vol. 42 (1984), pp. 197-203.

8. Price, J. and B. Yandle. "Labor Markets and Sunday Closing Laws." Journal of Labor Research (Fall, 1987), pp. 407-414.

9. Steel, R. G. D. and J. H. Torrie. Principles and Procedures of Statistics, 2nd Edition. New York, NY: McGraw-Hill (1980).

10. Tullock, G. "The Transitional Gains Trap." The Bell Journal of Economics, Vol. 6, No. 2 (1975), pp. 671-78.

11. U. S. Department of Commerce. 1982 Census of Retail Trade: Geographic Area Series. Washington, DC: Bureau of the Census (1984). 